\title{
EFFECTS OF THERMAL CONDITIONING DURING HATCHING AND EARLY GROWTH ON HEAT TOLERANCE OF JAPANESE QUAIL
}

\author{
H.A. Khalii ${ }^{1}$, A.M. Hassanein ${ }^{1}$, M.E. Mady ${ }^{1}$ and M. Gerken ${ }^{2}$
}

1- Department of Animal Production, Faculty of Agriculture, University of Suez Canal, Ismailia, Egypt, 2- Institute of Animal Breeding and Genetics, University of Göttingen, Albrecht Thaer Weg 3, 37075 Göttingen, Germany

\section{SUMMARY}

The purpose of the present study was to investigate the effect of thermal conditioning on heat tolerance of Japanese quail. A $3 \times 2$ factorial experimental design included three incubation temperature treatments: low $\left(L, 36.1^{\circ} \mathrm{C}\right)$, control $\left(C, 37.7^{\circ} \mathrm{C}\right)$ and high $(H$, $39.4^{\circ} \mathrm{C}$ ), and two housing temperatures: natural winter climate ( $N$, average, $\left.25.7^{\circ} \mathrm{C}\right)$ and constant high $\left(H, 35.0^{\circ} \mathrm{C}\right)$. A total of 360 chicks were involved (60 in each experimental group). Data were collected on body weight, feed intake and conversion, rectal temperature, hematocrit, oviposition day time and mortality rate until $14 \mathrm{wks}$ of age.

Incubation treatments had significant impacts on most of the studied traits. Juvenile body weight was depressed in birds incubated at low temperature. From 6 wks, however, birds incubated at high temperature reached the highest body weights under housing heat stress indicating long-term adaptation effects of incubation under high temperature.

High housing temperature exerted significant adverse effects on most of the studied traits. Rectal temperatures were significantly higher in heat stressed birds (42.57 vs. $41.92^{\circ} \mathrm{C}$ ). Total mortality rate was increased under high temperature (22.8 vs. $\left.17.8 \%\right)$.

It was concluded that, adequately increased incubation temperature might help to increase heat tolerance in particular in adult Japanese quail by enhancing early physiological adaptation processes.

Keywords: Japanese quail, thermal conditioning, heat stress, body weight, rectal temperature, hematocrit value, oviposition day time

\section{INTRODUCTION}

High ambient temperature has a negative effect on Japanese quail performance and broiler production (Sandercock et al., 2001 and Khalil, 1998 \& 2004). Increasing the environmental temperature by thermal conditioning at early age increased heat tolerance in birds (Sykes and Fataftah, 1986; Sykes and Silah, 1986; Arjona et al., 1988; Zhou et al., 1997; Yahav et al., 1997 and Tzschentke et al., 2001 \& 2002).

Arjona et al. (1988) found that, early age thermal conditioning caused a significant decrease in mortality rates and increase in feed efficiency when broiler chicks were exposed to a high environmental temperature at 42 day of age compared with control group. Similar improvements in chicken performance were reported by De Basilio et al. (2001) and Yahav and McMurtry (2001). They found that early age thermal conditioning caused increase in growth rate and feed efficiency by $(+4 \%)$ in heat stressed group compared with control group. Also, mortality rate during later heat stress was reduced in heated group compared with control group.

Issued by The Egyptian Society of Animal Production 
Body temperature is a good indicator of the level of metabolic rate and is directly linked to acclimation, the major metabolic hormone (triiodothyronine) decreased during heat stress (Hai Lin et al., 2006). Chicks exposed to early heat stress, maintained lower triiodothyronine concentration during their life span. Thus, the relationship between low metabolic rate and relatively low body temperature can predict the ability to successfully coping with thermal challenge or improvement in thermotolerance (May et al., 1997; Yahav et al., 1997; Yahav and Plavink, 1999; Yahav, 2000; Yahav and MCMurty, 2001 and Moraes et al., 2003).

The aim of the present study was to evaluate (i) the response of Japanese quail to heat stress (during housing) and (ii) the influence of thermal conditioning during hatching on subsequent heat tolerance in the adult birds.

\section{MATERIALS AND METHODS}

\section{Birds, feed and management}

The experimental work was carried out at the Poultry Farm, Department of Animal Production, Faculty of Agriculture, Suez Canal University, Ismailia, Egypt. The experiment was arranged in $3 \times 2$ factorial design, which resulted in six experimental groups.

Three incubation temperatures were used: low $\left(\mathrm{L}, 36.1^{\circ} \mathrm{C}\right)$, control $\left(\mathrm{C}, 37.7^{\circ} \mathrm{C}\right)$ and high $\left(\mathrm{H}, 39.4^{\circ} \mathrm{C}\right)$. After hatching the chicks were subjected to one of two different ambient temperatures in different rooms $(3 \times 3 \mathrm{~m})$. High $\left(35.0^{\circ} \mathrm{C}\right)$ and natural winter temperature $\left(25.7^{\circ} \mathrm{C}\right)$. The birds were kept in battery cages $(100 \times 80 \times 25 \mathrm{~cm})$ throughout the experimental period (14 weeks of age). The birds kept under continuous lighting program from the initial brooding period until 5 weeks of age after that, lighting was changed to give $16 \mathrm{~L}-8 \mathrm{D}$ per day until the end of the experiment. Both food and water were provided ad-libitum. The growing diets (0-6 wks of age) contained $24 \% \mathrm{CP}$ and $3000 \mathrm{Kcl}(\mathrm{ME}) / \mathrm{Kg}$ and laying diet (after $6 \mathrm{wks}$ ) containing $20 \% \mathrm{CP}$ and $3000 \mathrm{Kcl}(\mathrm{ME}) / \mathrm{Kg}$.

Three hundred and sixty unsexed one-day-old quail chicks were used in this experiment (60 chicks in each treatment group (Table 1). Temperature and relative humidity $(\mathrm{RH})$ were recorded daily during the experimental period. Average temperature and relative humidity were $\left(25.7^{\circ} \mathrm{C} \& 46.05 \%\right)$ in room under natural winter climatic conditions and $\left(35.0^{\circ} \mathrm{C} \& 51.71 \%\right)$ in heated room.

Table 1. Number of chicks under each experimental treatment

\begin{tabular}{|c|c|c|c|c|c|c|}
\hline \multirow{4}{*}{ Sex } & \multicolumn{6}{|c|}{ Incubation treatment (temperature) } \\
\hline & \multicolumn{2}{|c|}{ Low $\left(36.1^{\circ} \mathrm{C}\right)$} & \multicolumn{2}{|c|}{ Control $\left(37.7^{\circ} \mathrm{C}\right)$} & \multicolumn{2}{|c|}{ High $\left(39.4^{\circ} \mathrm{C}\right)$} \\
\hline & \multicolumn{6}{|c|}{ Housing temperature } \\
\hline & Natural* & High** & Natural & High & Natural & High \\
\hline Males & 32 & 35 & 31 & 34 & 32 & 26 \\
\hline Females & 28 & 25 & 29 & 26 & 28 & 34 \\
\hline Total & 60 & 60 & 60 & 60 & 60 & 60 \\
\hline
\end{tabular}

\section{Studied Traits}

1- Body weight, weight gain, feed conversion and mortality rate

Live body weights of male and female quails were recorded at weekly intervals till 6 weeks and biweekly till 14 weeks of age. Feed consumption was recorded 
during 1- 6 weeks of age. Weight gain and feed conversion values were calculated, the mortality rate was recorded during two period of age, 0-6 and 6-14 weeks.

\section{2- Body temperature}

Body temperature $\left({ }^{\circ} \mathrm{C}\right)$ was recorded at 2, 6, 10 and 14 weeks of age in 20 birds (10 males and 10 females) in each group by inserting a thermometer $1.5 \mathrm{~cm}$ into the cloaca for one minute.

\section{3- Blood samples}

A total of 256 blood samples were obtained at 3, 6, 12 and 14 weeks of age from 16 birds in each treatment group ( 8 males and 8 females). The hematocrit value was recorded after centrifuging the samples at $3000(\mathrm{r} / \mathrm{min})$ for 15 minutes.

\section{4- Oviposition day time}

Ninety-six 12-week-old females (16 hens from each treatment group) were held in individual cages and were used to record the oviposition day time. The oviposition day time and the average time interval (hr) between two consecutive days were recorded daily from 13.00 till 22.00 o'clock for 5 consecutive days. The oviposition incidence for each individual hen was recorded using a special instrument designed by Mady (1996). The percentages of eggs before and after 17.00 o'clock were computed.

\section{Statistical Analyses}

Data were analysed using the General Linear Model (GLM) procedure of SAS (SAS Institute Inc., 1998). Least Square Means (LSM) were calculated, and Least Square Differences (LSD) differentiated differences among mean were tested.

\section{RESULTS AND DISCUSSION}

\section{Body weight and gain}

Body weights of male and female quails with respect to incubation and housing temperatures are presented in Table (2). Birds hatched from eggs incubated at the low temperature had a highly significantly lighter weight at 6 weeks of age, whether housed under winter climate or under constant high temperature. While the heaviest values were obtained in birds incubated at high temperature at 6,10 and 14 weeks of age.

Data in Table (3) show weight gain of male and female quails as affected by incubation and housing temperatures. Through the period from hatching to 6 weeks of age, birds hatched from control and high temperatures gave significantly greater weight gain than those incubated at low temperature under the two housing conditions.

High housing temperature caused reduction in body weight and weight gain from any of the incubated groups. Birds kept under natural winter climate had significantly greater values than those kept under constant high temperature. Present results indicate that, juvenile body weight was depressed in birds incubated at low temperature, from 6 weeks of age, however, birds incubated at high temperature reached heaviest body weights under the hot environment (Table 2), indicating long term adaptation effects. Also, high housing temperature exerted significant adverse effects on body weight and weight gain. These results are consistent with many investigations. Body weight and weight gain were significantly reduced in chicks 
housed under high temperature $30-35^{\circ} \mathrm{C}$ as compared to those housed under moderate temperature $20-25^{\circ} \mathrm{C}$ (Leeson and Caston, 1993; Eberhart and Washburn, 1993; Peguri and Coon, 1993; Mioya and Picard, 1994 and Khalil, 1998 \& 2004). Several authors stated that increasing environmental temperature increased heat tolerance in birds (such as early age thermal conditioning). On the contrary, lowering the temperature during hatching or early age of live can reduce the bird's ability to tolerate heat stress (Sykes and Fataftah, 1986; Sykes and Silah, 1986; Arjona et al., 1988; Zhou et al., 1997; Yahav et al., 1997; De Basilio et al., 2001; Tzschentke, 2002 and Moraes et al., 2003).

\section{Feed intake and feed conversion}

Data in Table (3) show the average amounts of feed consumed by quail chicks and feed conversion under different temperature treatments. Feed intake and conversion rate were affected by incubation temperatures. Birds incubated at control temperature consumed more feed than those incubated at high and low temperature $(674.13,659.15$ and $571.50 \mathrm{~g} / \mathrm{b}$, respectively), however feed conversion was improved in birds incubated at low and high temperatures than those incubated at control temperature $(3.35,3.44$ and 3.62 , respectively) through the period $0-6$ weeks of age irrespective of housing temperatures. Housing hot condition reduced the amount of feed consumed/chick as compared with control condition. Birds housed under normal winter temperature consumed more feed than those housed under heat stress (678.34 vs. $598.45 \mathrm{~g} / \mathrm{b}$, respectively), but heat stress improved, slightly, feed conversion than the control condition (3.40 vs. 3.54, respectively), throughout the period 0-6 weeks of age irrespective of incubation temperatures.

These results agree with those obtained by Payne (1967) and Khalil (1998 \& 2004) who reported that, feed intake was significantly reduced when exposing birds to high environmental temperature $\left(30^{\circ} \mathrm{C}\right)$. Because the thermostatic mechanism of feed intake regulation results in an inverse relationship between environmental temperature and feed intake and the energy in consumed feed.

\section{Rectal temperature}

Effects of different incubation and housing treatments on rectal temperature of male and female quails are presented in Table (4). From 2 to 14 weeks of age, there were significant differences $(\mathrm{P} \leq 0.01)$ between the housing groups. All groups housed under heat stress had significantly higher rectal temperature compared with the groups housed under natural winter temperature. Birds incubated at low temperature and housed under hot temperature had significantly higher rectal temperature than those incubated at control and high temperature at 6 and 10 weeks of age. However, the lowest values were obtained in the birds incubated at control temperature under both natural and high housing temperatures at the same ages. The females had significantly higher rectal temperature than the males (42.21 vs. 41.86) at all studied ages irrespective of incubation and housing temperatures and age.

These results agree with Becker and Harrison (1975) and Walter and Paul (1975) who found that, Japanese quail reared for 14 days under 4 temperature treatments $\left(20,25,30\right.$ and $\left.35^{\circ} \mathrm{C}\right)$ showed negative correlation $(\mathrm{r}=-0.90)$ between heat production by their body and ambient temperature, with the most rapid change $\left(-4.5 \% / 1{ }^{\circ} \mathrm{C}\right)$ occurring between 20 and $25^{\circ} \mathrm{C}$. The rate of change with temperature then averaged $\left(-1.5 \% / 1^{\circ} \mathrm{C}\right)$ and flanked between 25 and $35^{\circ} \mathrm{C}$. They also reported that, female's body temperature was higher than the males. 
Khalil et al. 
Khalil et al. 


\section{Hematocrit values}

Results in Table (5) showed that, the males had significantly higher hematocrit values than the females at all studied ages with average (30.37 vs. $27.18 \%$ ). Also, juvenile birds had highly significant lower hematocrit values than in adult birds (26.83, 29.32, 29.77 and 29.27 at 3, 6, 12 and 14 weeks of age irrespective to treatments. Hosing temperatures had a significant effect on hematocrit value. The birds housed under natural temperature had significantly higher values than the birds housed under high temperature at 3 and 14 weeks of age. Also, incubation temperatures had significant effect on hematocrit value. The birds hatched under low temperature had higher values than the birds hatched under other treatments. The definition of high and low hematocrit value is somewhat difficult as this may vary greatly, depending on environmental factors related to ambient temperature, age, sex, water intake, dietary sodium, copper and iron (Goodwin et al., 1992). Khalil et al. (2006) found that a negative correlation between both feed intake and water consumed and hematocrit values (-0.16 and -0.39), respectively with highly significant correlation in Japanese quail. In the present study, the deprivation of feed and increase water consumed during the high housing temperature may be decreased hematocrit values.

\section{Oviposition day time}

Effects of different incubation and housing temperatures on oviposition day time are presented in Table (6). Birds hatched under low temperature showed significantly higher percentage of egg laid before 1700 o'clock compared with the other groups. Also, highly significant differences $(\mathrm{P} \leq 0.01)$ were found between the housing groups in oviposition time. Birds housed under constant heat stress showed higher percentage of eggs laid before 1700 o'clock than those housed under natural winter conditions ( 45.00 vs. $25.66 \%$, respectively). These results indicate that, birds housed under hot temperature were earlier in egg laying before the night, compared with those housed under natural winter temperature. Heat stress may be accelerate egg formation.

Table 6. Oviposition time and egg laid (\%) before and after 1700 o'clock with respect to incubation and housing temperatures

\begin{tabular}{lcc}
\hline Incubation temperature & $\begin{array}{c}\text { Before 1700 o'clock } \\
(\%)\end{array}$ & $\begin{array}{c}\text { After 1700 o'clock } \\
(\%)\end{array}$ \\
\hline Low (L) Housing temperature & & \\
$\quad$ Natural & $42.40 \pm 11.08^{\mathrm{a}}$ & $57.80 \pm 11.18^{\mathrm{a}}$ \\
$\quad$ High & $51.60 \pm 25.85^{\mathrm{a}}$ & $48.40 \pm 25.85^{\mathrm{b}}$ \\
$\quad$ Overall mean & $47.00 \pm 15.12^{\mathrm{a}}$ & $53.10 \pm 18.15^{\mathrm{b}}$ \\
Control (C) Housing temperature & & \\
$\quad$ Natural & $20.40 \pm 13.33^{\mathrm{b}}$ & $80.20 \pm 13.29^{\mathrm{a}}$ \\
$\quad$ High & $42.20 \pm 15.44^{\mathrm{a}}$ & $57.80 \pm 15.44^{\mathrm{b}}$ \\
$\quad$ Overall mean & $31.30 \pm 20.45^{\mathrm{b}}$ & $69.00 \pm 20.15^{\mathrm{a}}$ \\
High (L) Housing temperature & & \\
$\quad$ Natural & $14.20 \pm 7.56^{\mathrm{b}}$ & $85.80 \pm 7.56^{\mathrm{a}}$ \\
$\quad$ High & $41.20 \pm 21.41^{\mathrm{a}}$ & $58.80 \pm 21.41^{\mathrm{b}}$ \\
$\quad$ Overall mean & $27.70 \pm 14.13^{\mathrm{b}}$ & $72.30 \pm 14.12^{\mathrm{a}}$ \\
\hline
\end{tabular}


Khalil et al. 


\section{Mortality rate}

The average mortality rate of Japanese quail males and females as affected by incubation and housing temperatures are presented in Table (7). Birds housed under heat stress showed higher mortality rate than birds housed under natural winter conditions ( 22.77 vs. $17.77 \%$, respectively) irrespective of incubation treatments.

The highest mortality rate was found in birds incubated at high temperature, while the lowest value was found in birds incubated at control temperature, under high housing temperature ( 26.66 vs. $18.33 \%$, respectively). On the other hand, under normal winter conditions, the highest mortality rate was obtained in birds incubated at control temperature, while the lowest rate was found in birds incubated at low temperature ( 23.33 vs. $11.66 \%$, respectively).

In general high housing temperatures exerted significant adverse effects on most traits studied. However, thermal conditioning during incubation improved adaptation to heat stress in adult birds. It is concluded that, adequately increased incubation temperature might help to increase heat tolerance particularly in adult Japanese quail by enhancing early physiological adaptation processes.

\section{REFERENCES}

Arjona, A. A., D. M. Denbow and W. D. Weaver, 1988. Effect of heat stress early life on mortality of broilers exposed to high environmental temperatures just prior to marketing. Poultry Sci., 67:226-231.

Becker, W. A. and P. Harrison, 1975. Genetic variation of body temperature of Coturnix coturnix in two ambient temperatures. Poultry Sci., 54: 3, 688-695.

De Basilio, V., M. Vilarino, S. Yahav and M. Picards, 2001. Early age thermal conditioning and a dual feeding program for male broilers challenged by heat stress. Poultry Sci., 80: 29-36.

Eberhart, D. E. and K. W. Washburn, 1993. Assessing the effect of the naked neck gene on chronic heat stress resistance into genetic population. Poultry Sci., 72 (8) 13911399.

Goodwin, M., J. Davis and J. Brown, 1992. Packed cell volume reference intervals to aid in the diagnosis of anemia and polycythemia in young broiler chickens. Avian Dis., 36:440-443.

Hai Lin, Eddy Decuypere and Johan Buyse, 2006. Acute heat stress induces oxidative stress in broilers chickens. Comparative Biochemistry and Physiology (A) 11-17.

Khalil, H. A., 1998. Seasonal variation in production and fertility of Japanese quail (Coturnix coturnix japonica). M.Sc. Thesis, Suez Canal University, Faculty of Agriculture.

Khalil, H. A., 2004. Productive and Reproductive Aspects of Japanese Quail (Coturnix coturnix japonica) under heat stress conditions Ph.D. Thesis, Suez Canal University, Faculty of Agriculture.

Khalil, H. A., A. M. Hassaein, M. E. Mady and M. Gerken, 2006. Effect of housing conditions on performance of Japanese quail under cold stress in winter. Egypt. J. Anim. Prod., 43 (1):71-82.

Leeson, S. and L. J. Caston, 1993. Does environment temperature influence body weight: Shank length in Leghorn pullets. Journal of Applied Poultry Research, 2 (3) $245-248$. 
Mady, M. E., 1996. Accurate and simple instrument for detection of time of oviposition in Poultry. (Potent Office) Egyptian Academy of Scientific Research and Technology, Cairo, Egypt.

May, J. D., J. Deaton and A. Branton, 1997. Body temperature of acclimated broilers during exposure to high temperature. Poultry Sci., 66:378-380.

Mioya, J. and M. Picard, 1994. Climatic adaptation of laying hens. Tropical Animal Health and Production, 26(3) 180-186.

Moraes, V.M.B., R.D. Malheirs, V. Bruggeman, A. Collin, K. Tona, P. Van As, O. M. Onagbesan, J. Buyse, E. Decuypere and M. Macari, 2003. Effect of thermal conditioning during embryonic development on aspects of physiological responses of broilers to heat stress. Journal of Thermal Biology, (28) 133-140.

Payne, C. G., 1967. Day-length during rearing and subsequent egg production of meat strain pullets. British Poultry Sci., 16:559-563.

Peguri, A. and C. Coon, 1993. Effect of feather coverage and temperature on layer performance. Poultry Sci., 72 (7) 1318 - 1329.

Sandercock, D. A., R. R. Hunter, G. R. Nute, M. A. Mitchell and P. M. Hoching, 2001. Acute heat stress-induced alterations in blood acid-base status and skeletal muscle membrane integrity in broiler chickens at two ages: implication for meat quality. Poultry Sci., 80: 418-425.

SAS Institute, 1998. SAS statistical guide for personal computer, SAS Institute Inc. Cary, NC.

Sykes, A. H. and A. R. Fataftah, 1986. Effect of a change in environmental temperature on heat tolerance in laying fowl. British Poultry Sci., 27: 307-316.

Sykes, A. H. and F. I. Silah, 1986. Effect of changes of dietary energy intake and environmental temperature on heat tolerance in the fowl. British Poultry Sci., 27: 687-693.

Tzschentke, B., D. Basta, A. Winar, B. Hahn, and M. Nichelmann, 2002. Perinatal development of thermoregulation and the influence of epigenetic temperature adaptation in poultry-importance for animal welfare. $11^{\text {th }}$ European Poultry Conference, 6-10 September, Bremen, Germany.

Tzschentke, B., D. Basta, and M. Nichelmann, 2001. Epigenetic temperature adaptation in birds: peculiarities and similarities in comparison to acclimation. News of Biomedical Sci., N 1, 26-31.

Walter, A. B. and H. Paul, 1975. Genetic variation of body temperature of Coturnix coturnix in two ambient temperatures. Poultry Sci., 54 : 688-695.

Yahav, S. and I. Plavink, 1999. Effect of early-age thermal conditioning and food restriction on performance and thermotolerance of male broiler chikens. British Poultry Sci., 40:120-126.

Yahav, S. and J. P. McMurty, 2001. Thermotolerance acquisition in broiler chickens by temperature conditioing early in life-the effect of timing and ambient temperature. Poultry Sci. 80:1662-1666.

Yahav, S., 2000. Demostic fowl-strategies to confront environmental conditions. Avian. Poultry Biol. Rev., 11:81-95.

Yahav, S., A. Shamai, A. Haberfield, G., S. Horus, M. Hurwitz, and I. Plavink, 1997. Induction of thermotolerance in chikens by temperature conditioning: Heat shock protein expression. Update in thermoregulation from cellular function to clinical relevance. Ann. New York Acad. Sci., 813:628-636. 
Yahav, S., D. Luger, A.,Cahaner, M. Dotan, M. Rusal. and S. Hurwitz, 1997. Thermoregulation in naked neck chickens subjected to different ambient temperatures. British, Poultry Sci., 39: 133-138.

Zhou, W., M. Fujita, T. Ito and S.Yamamoto, 1997. Effects of early heat exposure on thermoregulatory responses and blood viscosity of broilers prior to marketing. British Poultry Sci., 38: 301-306. 


\title{
دراسة أثر النظم الحراريـة أثنـاء التفريخ والنمو المبكر على التحمل الحرارى في السمان اليابانى
}

\author{
حسن عبد الغفار خليل 1. أحمد محمد حسنين 1ـ محمد السيد ماضى 1ـ مارتينا جركن 2 \\ 1- كلية الزراعة، جامعة قنـاة السويس، الإسعاعيلية، مصر. 2- معهل بحوث الإنتاج الحيوانس، جامعة \\ جوتنجن، ألمانيا
}

أستهدفت هذه التجربـة دراسة تأثير الحر ارة المرتفعـة داخل ماكينـات التفريخ ومساكن التربيـة على أداء

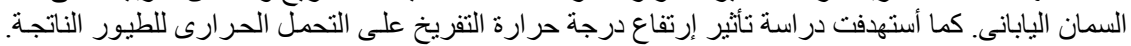

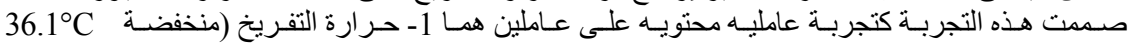

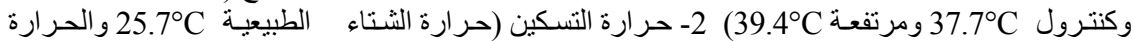
المرتفعة 35.0² $)$ وكانت أهم النتائج المتحصل عليها ما يلى:

1- وجد أن الطيور الفاقسة على درجة الحر ارة المنذفضة كانت الأقل معنويا فى وزن الجسم فى معظم الأعمار

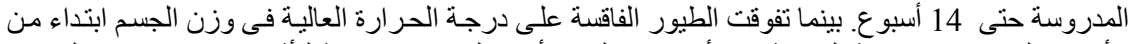

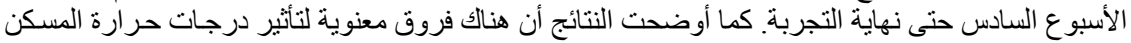

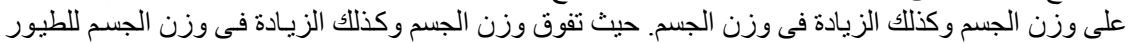

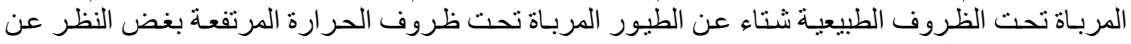

معاملات حرارة التفريخ.

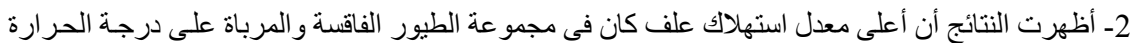

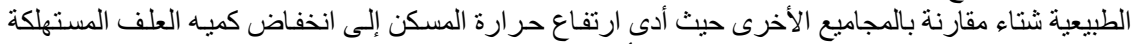

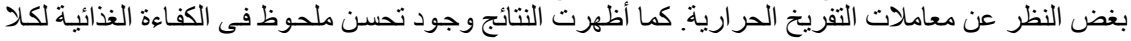

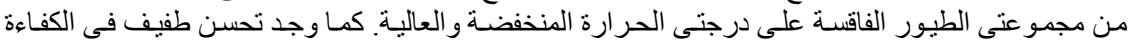

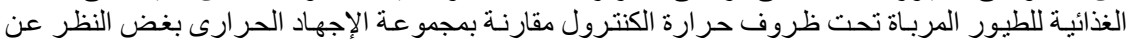

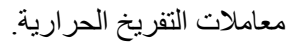

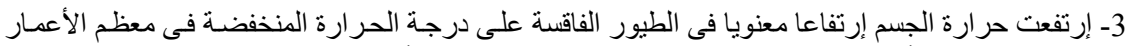

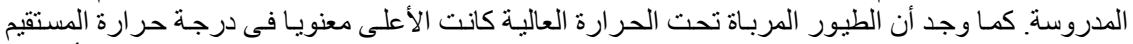

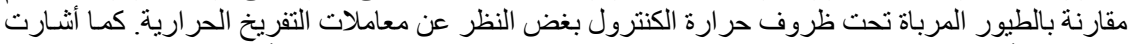

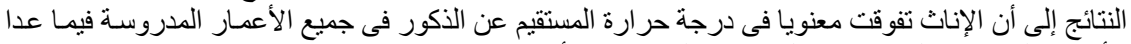

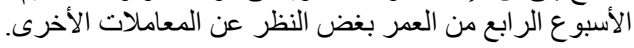

4ـ أظهرت النتائج أن الذكور تفوقت معنويا عن الإناث فى قيم الهيماتوكريت في جميع الأعمار المدروسـة. كما

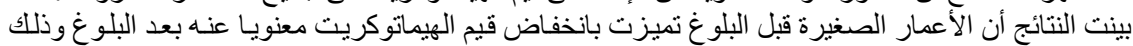

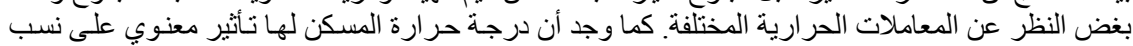

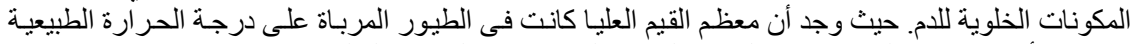

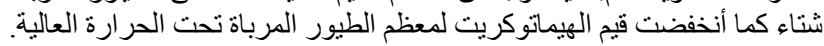

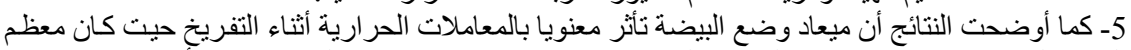

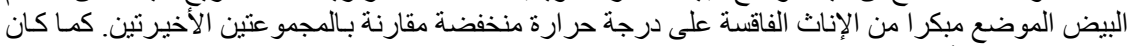

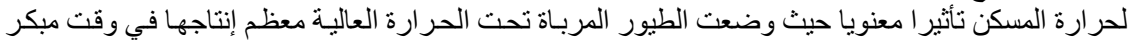
مقارنة بالطيور المر اباة تحت درجة الحر ارة الطبئ الطبيعية شتاء. 


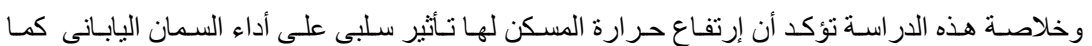

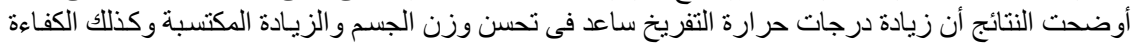

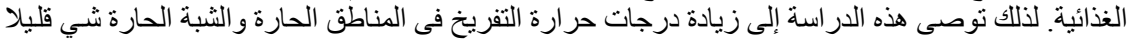
حتى يزداد التحمل الحراري لدى لودى الطيور الناتجة. 
Khalil et al. 
Egyptian J. Anim. Prod., (2008) 45(1):55-69

Table 2. Body weight (g) of male and female quails at successive ages with respect to incubation and housing temperatures (LSQ-Means \pm SD)

\begin{tabular}{|c|c|c|c|c|c|c|c|}
\hline \multirow{3}{*}{$\begin{array}{c}\text { Age } \\
\text { (wk) }\end{array}$} & \multirow{3}{*}{ Sex } & \multicolumn{6}{|c|}{ Incubation temperature } \\
\hline & & \multicolumn{2}{|c|}{$\begin{array}{c}\text { Low }(\mathrm{L}) \\
\text { Housing temperature }\end{array}$} & \multicolumn{2}{|c|}{$\begin{array}{c}\text { Control (C) } \\
\text { Housing temperature }\end{array}$} & \multicolumn{2}{|c|}{$\begin{array}{c}\text { High }(\mathrm{H}) \\
\text { Housing temperature }\end{array}$} \\
\hline & & Natural & High & Natural & High & Natural & High \\
\hline \multirow{4}{*}{2} & Male & $54.50 \pm 8.24^{b}$ & $50.87 \pm 7.06^{\mathrm{b}}$ & $61.19 \pm 8.29^{\mathrm{a}}$ & $58.48 \pm 8.24^{\mathrm{a}}$ & $53.34 \pm 7.45^{\mathrm{b}}$ & $52.46 \pm 5.54^{b}$ \\
\hline & Female & $55.85 \pm 8.31^{b}$ & $55.56 \pm 9.41^{b}$ & $62.60 \pm 8.21^{\mathrm{a}}$ & $62.04 \pm 7.74^{\mathrm{a}}$ & $56.10 \pm 9.24^{b}$ & $51.02 \pm 6.25^{\mathrm{c}}$ \\
\hline & Overall & $55.17 \pm 8.25^{b}$ & $53.21 \pm 8.57^{b c}$ & $61.86 \pm 8.25^{a}$ & $60.26 \pm 7.84^{\mathrm{a}}$ & $54.72 \pm 8.14^{b c}$ & $51.74 \pm 5.68 \mathrm{c}^{\mathrm{c}}$ \\
\hline & Male & $179.92 \pm 17.39^{b}$ & $167.22 \pm 13.87^{\mathrm{c}}$ & $190.17 \pm 17.87^{\mathrm{a}}$ & $177.54 \pm 18.25^{\mathrm{b}}$ & $191.78 \pm 13.35^{\mathrm{a}}$ & $184.76 \pm 12.94^{\mathrm{ab}}$ \\
\hline \multirow[t]{3}{*}{6} & Female & $197.51 \pm 21.24^{b}$ & $179.40 \pm 19.97^{\mathrm{c}}$ & $216.78 \pm 20.37^{\mathrm{a}}$ & $196.25 \pm 20.38^{b}$ & $222.00 \pm 25.36^{\mathrm{a}}$ & $199.13 \pm 17.94^{b}$ \\
\hline & Overall & $188.71 \pm 19.26^{b}$ & $173.31 \pm 15.69^{c}$ & $203.48 \pm 18.64^{a}$ & $186.89 \pm 19.28^{b}$ & $206.89 \pm 18.67^{a}$ & $191.94 \pm 15.12^{b}$ \\
\hline & Male & $191.07 \pm 11.16^{\mathrm{bc}}$ & $185.53 \pm 13.36^{\mathrm{c}}$ & $203.25 \pm 24.26^{\mathrm{a}}$ & $189.67 \pm 19.34^{b c}$ & $203.00 \pm 22.64^{\mathrm{a}}$ & $199.16 \pm 19.62^{\mathrm{ab}}$ \\
\hline \multirow[t]{3}{*}{10} & Female & $224.20 \pm 15.64^{b}$ & $207.75 \pm 19.37^{\mathrm{c}}$ & $248.26 \pm 19.34^{\mathrm{a}}$ & $207.73 \pm 17.54^{\mathrm{c}}$ & $238.15 \pm 25.94^{\mathrm{a}}$ & $211.95 \pm 12.28^{\mathrm{c}}$ \\
\hline & Overall & $207.63 \pm 13.61^{b}$ & $196.64 \pm 16.39^{\mathrm{c}}$ & $225.75 \pm 22.67^{\mathrm{a}}$ & $198.71 \pm 18.64^{b c}$ & $220.56 \pm 23.69^{a}$ & $205.55 \pm 15.94^{b}$ \\
\hline & Male & $207.71 \pm 19.64^{\mathrm{abc}}$ & $202.80 \pm 16.62^{b c}$ & $213.80 \pm 26.31^{\mathrm{ab}}$ & $197.85 \pm 16.04^{\mathrm{c}}$ & $215.80 \pm 18.25^{\mathrm{a}}$ & $214.43 \pm 4.28^{\mathrm{ab}}$ \\
\hline \multirow[t]{2}{*}{14} & Female & $246.08 \pm 16.37^{\mathrm{a}}$ & $222.15 \pm 13.58^{b}$ & $251.40 \pm 25.22^{\mathrm{a}}$ & $206.42 \pm 21.64^{\mathrm{c}}$ & $252.45 \pm 32.68^{\mathrm{a}}$ & $221.25 \pm 3.53^{b}$ \\
\hline & Overall & $226.89 \pm 18.06^{a b}$ & $212.47 \pm 14.36^{\mathrm{cd}}$ & $232.61 \pm 25.69^{\mathrm{a}}$ & $201.92 \pm 18.94^{d}$ & $234.12 \pm 25.58^{\mathrm{a}}$ & $217.84 \pm 2.83{ }^{b c}$ \\
\hline
\end{tabular}

$\mathrm{a}, \mathrm{b}, \mathrm{c}$ Means with the same letter in each row are not significantly different $(\mathrm{P} \leq 0.05)$. 
Table 3. Weight gain, feed intake and food conversion of quails with respect to incubation and housing temperatures (LSQ-Means \pm SD)

\begin{tabular}{|c|c|c|c|c|c|c|c|}
\hline \multirow[t]{2}{*}{ Parameters } & \multirow[t]{2}{*}{$\begin{array}{l}\text { Age } \\
\text { (Wks) }\end{array}$} & \multicolumn{4}{|c|}{$\begin{array}{c}\text { Incubation temperature } \\
\text { Control (C) } \\
\text { Housing temperature }\end{array}$} & \multicolumn{2}{|c|}{$\begin{array}{c}\text { High }(\mathrm{H}) \\
\text { Housing temperature }\end{array}$} \\
\hline & & Natural & High & Natural & High & Natural & High \\
\hline \multirow{4}{*}{ Weight gain (g) } & $0-2$ & $47.41 \pm 8.15^{\mathrm{b}}$ & $45.61 \pm 8.26^{\mathrm{bc}}$ & $53.36 \pm 8.39^{\mathrm{a}}$ & $51.72 \pm 7.94^{\mathrm{a}}$ & $46.42 \pm 8.16^{\mathrm{bc}}$ & $43.55 \pm 5.64^{\mathrm{c}}$ \\
\hline & $2-4$ & $73.08 \pm 10.39^{b}$ & $62.38 \pm 9.67^{\mathrm{c}}$ & $89.75 \pm 11.64^{\mathrm{a}}$ & $75.78 \pm 9.64^{b}$ & $89.47 \pm 10.29^{\mathrm{a}}$ & $84.68 \pm 12.64^{\mathrm{a}}$ \\
\hline & $4-6$ & $60.32 \pm 15.64^{\mathrm{a}}$ & $57.02 \pm 10.64^{\mathrm{ab}}$ & $51.14 \pm 15.67^{\mathrm{b}}$ & $50.91 \pm 11.71^{b}$ & $62.51 \pm 18.64^{\mathrm{a}}$ & $55.03 \pm 11.93^{\mathrm{ab}}$ \\
\hline & $0-6$ & $180.94 \pm 18.69^{b}$ & $165.71 \pm 16.12^{\mathrm{c}}$ & $194.95 \pm 18.67^{\mathrm{a}}$ & $178.35 \pm 19.57^{b}$ & $198.59 \pm 19.25^{\mathrm{a}}$ & $183.75 \pm 15.36^{b}$ \\
\hline \multirow{4}{*}{$\begin{array}{l}\text { Feed intake/bird } \\
\text { (g) }\end{array}$} & 0-2 & 99.82 & 102.90 & 108.15 & 118.44 & 104.37 & 94.22 \\
\hline & $2-4$ & 221.13 & 190.40 & 252.84 & 235.76 & 264.11 & 203.91 \\
\hline & $4-6$ & 297.50 & 252.07 & 335.09 & 297.99 & 352.03 & 299.67 \\
\hline & $0-6$ & 618.45 & 545.37 & 696.08 & 652.19 & 720.51 & 597.80 \\
\hline \multirow{4}{*}{ Feed conversion } & 0-2 & 2.105 & 2.256 & 2.027 & 2.290 & 2.248 & 2.163 \\
\hline & $2-4$ & 3.025 & 3.052 & 2.820 & 3.111 & 2.951 & 2.408 \\
\hline & $4-6$ & 4.932 & 4.420 & 6.571 & 5.853 & 5.631 & 5.445 \\
\hline & $0-6$ & 3.417 & 3.291 & 3.571 & 3.656 & 3.628 & 3.253 \\
\hline
\end{tabular}

$\mathrm{a}, \mathrm{b}, \mathrm{c}$ Means with the same letter in each row are not significantly different $(\mathrm{P} \leq 0.05)$ 
Table 4. Rectal temperature of male and female quails with respect to incubation and housing temperatures (LSQ-Means \pm SD)

\begin{tabular}{|c|c|c|c|c|c|c|c|}
\hline \multirow[t]{2}{*}{$\begin{array}{c}\text { Age } \\
(\text { Wks })\end{array}$} & \multirow[t]{2}{*}{ Sex } & \multicolumn{2}{|c|}{$\begin{array}{c}\text { Low }(\mathrm{L}) \\
\text { Housing temperature }\end{array}$} & \multicolumn{2}{|c|}{$\begin{array}{l}\text { Incubation temperature } \\
\text { Control (C) } \\
\text { Housing temperature }\end{array}$} & \multicolumn{2}{|c|}{$\begin{array}{c}\text { High }(\mathrm{H}) \\
\text { Housing temperature }\end{array}$} \\
\hline & & Natural & High & Natural & High & Natural & High \\
\hline \multirow{3}{*}{2} & Male & $41.17 \pm 0.37^{b}$ & $41.77 \pm 0.34^{\mathrm{a}}$ & $41.21 \pm 0.12^{\mathrm{b}}$ & $41.93 \pm 0.34^{\mathrm{a}}$ & $41.41 \pm 0.39^{b}$ & $41.93 \pm 0.46^{\mathrm{a}}$ \\
\hline & Female & $41.38 \pm 0.41^{b}$ & $42.17 \pm 0.12^{\mathrm{a}}$ & $41.51 \pm 0.15^{\mathrm{c}}$ & $41.84 \pm 0.35^{\mathrm{b}}$ & $41.29 \pm 0.37^{\mathrm{c}}$ & $41.85 \pm 0.26^{b}$ \\
\hline & Overall & $41.27 \pm 0.39^{c}$ & $41.97 \pm 0.25^{\mathrm{a}}$ & $41.36 \pm 0.16^{b}$ & $41.88 \pm 0.45^{\mathrm{a}}$ & $41.35 \pm 0.34^{b}$ & $41.89 \pm 0.34^{\mathrm{a}}$ \\
\hline \multirow{3}{*}{6} & Male & $41.79 \pm 0.37^{b}$ & $42.17 \pm 0.39^{\mathrm{a}}$ & $41.37 \pm 0.21{ }^{\mathrm{cd}}$ & $41.54 \pm 0.38^{\mathrm{bc}}$ & $41.24 \pm 0.37^{\mathrm{d}}$ & $41.75 \pm 0.36^{b}$ \\
\hline & Female & $41.81 \pm 0.29^{\mathrm{bc}}$ & $42.58 \pm 0.16^{\mathrm{a}}$ & $41.57 \pm 0.26^{\mathrm{d}}$ & $41.86 \pm 0.32^{\mathrm{c}}$ & $41.53 \pm 0.19^{d}$ & $42.31 \pm 0.29^{b}$ \\
\hline & Overall & $41.80 \pm 0.39^{\mathrm{c}}$ & $42.37 \pm 0.26^{a}$ & $41.47 \pm 0.27^{d}$ & $41.71 \pm 0.26^{\mathrm{c}}$ & $41.38 \pm 0.39^{d}$ & $42.02 \pm 0.34^{b}$ \\
\hline \multirow{3}{*}{10} & Male & $41.78 \pm 0.29^{b c}$ & $42.28 \pm 0.36^{\mathrm{a}}$ & $41.59 \pm 0.34^{\mathrm{c}}$ & $41.97 \pm 0.26^{\mathrm{b}}$ & $41.65 \pm 0.26^{\mathrm{c}}$ & $42.19 \pm 0.16^{\mathrm{a}}$ \\
\hline & Female & $42.17 \pm 0.37^{\mathrm{b}}$ & $42.91 \pm 0.34^{\mathrm{a}}$ & $41.78 \pm 0.18^{\mathrm{c}}$ & $42.31 \pm 0.24^{\mathrm{b}}$ & $41.77 \pm 0.27^{\mathrm{c}}$ & $42.23 \pm 0.18^{b}$ \\
\hline & Overall & $41.97 \pm 0.311^{c}$ & $42.59 \pm 0.34^{\mathrm{a}}$ & $41.68 \pm 0.26^{d}$ & $42.14 \pm 0.23^{b c}$ & $41.71 \pm 0.36^{d}$ & $42.21 \pm 0.16^{b}$ \\
\hline \multirow{3}{*}{14} & Male & $41.91 \pm 0.23^{b c}$ & $42.04 \pm 0.38^{b}$ & $41.74 \pm 0.34^{\mathrm{c}}$ & $42.10 \pm 0.28^{b}$ & $41.76 \pm 0.34^{\mathrm{c}}$ & $42.49 \pm 0.24^{\mathrm{a}}$ \\
\hline & Female & $42.25 \pm 0.21^{\mathrm{c}}$ & $42.62 \pm 0.34^{b}$ & $42.28 \pm 0.36^{\mathrm{c}}$ & $42.34 \pm 0.39^{\mathrm{c}}$ & $42.31 \pm 0.32^{\mathrm{c}}$ & $43.00 \pm 0.34^{\mathrm{a}}$ \\
\hline & Overall & $42.08 \pm 0.24^{c}$ & $42.33 \pm 0.36^{b}$ & $42.01 \pm 0.36^{c}$ & $42.22 \pm 0.38^{b c}$ & $42.03 \pm 0.34 c$ & $42.74 \pm 0.29^{a}$ \\
\hline
\end{tabular}

$\mathrm{a}, \mathrm{b}, \mathrm{c}$ Means with the same letter in each row are not significantly different $(\mathrm{P} \leq 0.05)$. 
Table 5. Hematocrit values of male and female quail with respect to incubation and housing temperatures (LSQ-Means \pm SD)

\begin{tabular}{|c|c|c|c|c|c|c|c|}
\hline \multirow[t]{2}{*}{$\begin{array}{l}\text { Age } \\
(w k s)\end{array}$} & \multirow[t]{2}{*}{ Sex } & \multicolumn{2}{|c|}{$\begin{array}{c}\text { Low (L) } \\
\text { Housing temperature }\end{array}$} & \multicolumn{2}{|c|}{$\begin{array}{c}\text { Incubation temperature } \\
\text { Control (C) } \\
\text { Housing temperature }\end{array}$} & \multicolumn{2}{|c|}{$\begin{array}{c}\text { High }(\mathrm{H}) \\
\text { Housing temperature }\end{array}$} \\
\hline & & Natural & High & Natural & High & Natural & High \\
\hline \multirow{3}{*}{3} & Male & $29.55 \pm 4.67^{\mathrm{a}}$ & $27.85 \pm 3.15^{b c}$ & $26.74 \pm 4.36^{\mathrm{c}}$ & $28.44 \pm 2.36^{\mathrm{ab}}$ & $27.58 \pm 3.36^{b c}$ & $26.39 \pm 3.94^{c}$ \\
\hline & Female & $26.79 \pm 4.16$ & $26.44 \pm 3.54$ & $25.43 \pm 3.67$ & $25.80 \pm 3.67$ & $25.71 \pm 4.56$ & $25.34 \pm 3.64$ \\
\hline & Overall & $28.17 \pm 4.336^{\mathrm{a}}$ & $27.14 \pm 3.12^{a b}$ & $26.08 \pm 4.12^{b}$ & $27.12 \pm 2.94^{a b}$ & $26.64 \pm 3.56^{b}$ & $25.86 \pm 3.25^{b}$ \\
\hline \multirow[t]{3}{*}{6} & Male & $30.16 \pm 3.64^{\mathrm{a}}$ & $31.75 \pm 5.15^{\mathrm{a}}$ & $30.34 \pm 3.26^{\mathrm{a}}$ & $26.31 \pm 4.36^{\mathrm{b}}$ & $32.18 \pm 3.26^{\mathrm{a}}$ & $30.08 \pm 3.36^{\mathrm{a}}$ \\
\hline & Female & $28.16 \pm 3.17^{b}$ & $27.52 \pm 2.67^{b}$ & $27.24 \pm 2.29^{b}$ & $32.19 \pm 3.56^{\mathrm{a}}$ & $28.09 \pm 4.69^{b}$ & $27.92 \pm 2.56^{b}$ \\
\hline & Overall & $29.16 \pm 3.12$ & $29.63 \pm 3.18$ & $28.79 \pm 3.36$ & $29.25 \pm 4.26$ & $30.14 \pm 3.67$ & $29.00 \pm 3.05$ \\
\hline \multirow[t]{3}{*}{12} & Male & $32.58 \pm 4.16$ & $31.48 \pm 3.18$ & $32.24 \pm 3.67$ & $32.48 \pm 2.36$ & $31.16 \pm 2.56$ & $31.04 \pm 4.26$ \\
\hline & Female & $28.66 \pm 3.46^{\mathrm{a}}$ & $26.42 \pm 4.64^{b}$ & $27.79 \pm 2.67^{\mathrm{ab}}$ & $28.25 \pm 3.67^{\mathrm{a}}$ & $27.91 \pm 3.29^{\mathrm{ab}}$ & $27.24 \pm 2.25^{\mathrm{ab}}$ \\
\hline & Overall & $30.62 \pm 3.34$ & $28.95 \pm 3.94$ & $30.01 \pm 2.94$ & $30.37 \pm 2.97$ & $29.53 \pm 3.45$ & $29.14 \pm 3.26$ \\
\hline \multirow[t]{2}{*}{14} & Male & $33.45 \pm 4.16$ & $31.37 \pm 4.36$ & $31.51 \pm 2.37$ & $30.72 \pm 2.13$ & $32.83 \pm 3.69$ & $30.81 \pm 5.45$ \\
\hline & Female & $27.85 \pm 5.18^{\mathrm{a}}$ & $28.14 \pm 5.45^{\mathrm{a}}$ & $28.73 \pm 2.39^{\mathrm{a}}$ & $22.57 \pm 2.36^{\mathrm{b}}$ & $26.18 \pm 5.15^{\mathrm{a}}$ & $27.13 \pm 5.29^{\mathrm{a}}$ \\
\hline \multirow{4}{*}{ Overall } & Overall & $30.65 \pm 4.35^{\mathrm{a}}$ & $29.75 \pm 4.67^{\mathrm{a}}$ & $30.12 \pm 2.36^{\mathrm{a}}$ & $26.64 \pm 2.39^{b}$ & $29.51 \pm 4.64^{\mathrm{a}}$ & $28.96 \pm 5.34^{b}$ \\
\hline & Male & $31.43 \pm 4.13^{\mathrm{a}}$ & $30.61 \pm 3.25^{\mathrm{ab}}$ & $30.21 \pm 3.36^{\mathrm{ab}}$ & $29.49 \pm 3.45^{\mathrm{b}}$ & $30.94 \pm 3.45^{\mathrm{ab}}$ & $29.58 \pm 3.36^{b}$ \\
\hline & Female & $27.86 \pm 3.18$ & $27.13 \pm 3.19$ & $27.30 \pm 3.45$ & $27.21 \pm 4.26$ & $26.97 \pm 3.46$ & $26.91 \pm 3.46$ \\
\hline & Overall & $29.65 \pm 3.84^{a}$ & $28.87 \pm 3.39^{\mathrm{ab}}$ & $28.75 \pm 3.34^{\mathrm{ab}}$ & $28.34 \pm 3.67^{b}$ & $28.95 \pm 3.36^{\mathrm{ab}}$ & $28.24 \pm 3.12^{b}$ \\
\hline
\end{tabular}

$\mathrm{a}, \mathrm{b}, \mathrm{c}$ Means with the same letter in each row are not significantly different $(\mathrm{P} \leq 0.05)$. 